\title{
Chapter 4 \\ Vulnerability and Resilience \\ in the Covid-19 Crisis: Race, Gender, \\ and Belonging
}

\author{
Eileen Boris
}

\subsection{Introduction}

In the midst of surging sickness in Spring 2020, a typical newspaper headline read, "We're Ignored Completely." Amid the Pandemic, Undocumented Immigrants are Essential But Exposed' (Villa, 2020). Migrants who travelled to the United States to pick crops, scrub floors, stock warehouses, and tend to elders became 'heroes' for performing necessary labour - unless they were surplus bodies crammed into prison-like detention waystations before being deported for the crime of arriving without proper papers. They were not alone. From detention centres to refugee camps, from fields to homes, migrant workers worldwide faced deadly vulnerability during the Covid-19 crisis, made more virulent through racism and anti-immigrant nationalisms. Countries sought to close their borders to keep out disease. The pandemic intensified states of precarity, especially for undocumented, transgender, and gender non-conforming individuals and those from racially-othered groups. Women among them found new difficulties in meeting double obligations: to earn a living and care for households, both for family requiring daily tending and for those dependent on remittances sent back to countries of origin. Especially among those labelled as 'essential workers', the lack of protective equipment and labour rights put them on the frontline of exposure. But domestic and home care workers, meatpackers, fieldhands, and others in the US stepped out of the shadows to demand inclusion in social assistance, occupational health and safety laws, and other state benefits. They could not rely on the state even as they called for recognition and rights. So they developed mutual aid and coalitional activism to advance their dignity and improve living as well as working conditions.

With a focus on the US, for over two centuries a major destination for migrants, this chapter historicises the recent hardships and the organising of (im)migrant

\author{
E. Boris $(\square)$ \\ University of California, Santa Barbara, Santa Barbara, CA, USA \\ e-mail: eboris@ucsb.edu
}


workers. The Covid-19 spring is not the first time that state and society blamed immigrants for public health or economic crisis: these nativist outbreaks include anti-Asian uprisings on the West coast in the late nineteenth century, Mexican deportations in the early 1930s, immigrant exclusion from the New Deal welfare state, and periodic onslaughts since. A historical perspective shows that the policies of Donald J. Trump were not an aberration, but part of a national pattern of racial differentiation with gendered inflections. Vulnerability, however, is only part of the story. Workers remained resilient in the face of the hidden enemy of Covid-19 and the all too present assaults by employers and agents of the state, the latter who would exploit, detain and/or deport rather than protect those who grow our food and assist other people in their activities of daily life. Vulnerability takes on a new meaning with the recognition that we are all in this together.

\subsection{Blaming Migrants: The Vulnerable Past}

Understandings of whiteness, that designated only Northern Europeans and their descendants as fully 'white,' led to classifying most migrants as alien, especially if they also were poor. In speaking of the 'Chinese virus' and the 'Kung-flu', President Trump set the tone for hate speech toward Asians in the US, against which there were over 2100 reported incidents - including physical assaults and workplace discrimination - between March and July 2020. Asian American citizens were not exempt; they heard shouts of 'Take your disease that's ruining our country and go home' (Donaghue, 2020). The nation also listened to the President blame migrants for a June 2020 spike in cases in the US along the border shared with Mexico despite lowered numbers of crossings (Farley, 2020). Other officials followed, like Florida's Republican Governor Ron DeSantis, pointing to 'Hispanic' farmworkers as the culprit for the surge in Covid-19 in the Sunshine state (De Loera-Brust, 2020). This association of non-whites with disease, the Chinese with a killer virus, and Mexicans with viral spread, derived from linking citizenship to whiteness, in which even citizens from designated ethnic or racial groups appeared as foreign. In 1944, the federal government gained the power to reject on the basis of 'public health threats' any individual who sought to come into the country. Nearly 80 years later the administration would attempt to weaponise that tool against asylum seekers, temporary migrants, and long-time denizens alike (Chishti \& Pierce, 2020).

In early America, migrant workers disproportionately suffered from cholera and other airborne killers. Nativists accused the Irish in the 1830s of bringing infection into the US along with themselves. During the first great wave of immigration after the Civil War, when 23.5 million people arrived between 1880 and the 1920s, the medicalisation of control classified them as spreaders rather than victims of pathogens. When their numbers soared at the end of the nineteenth century, Jews were cast as carriers of 'the tailor's disease' or tuberculosis. Italians, it was charged, sparked a polio outbreak in New York City because of family gatherings and sickbed practices (Kraut, 2010; Moloney, 2012, 105-133). Racism and fear of 
economic competition came together in frenzies of anti-immigrant actions among public officials as well as among workingmen fearful of losing their jobs to lowerwaged 'coolie' labour (Mink, 1990; Saxton, 1971). As a North Carolina health official testified before Congress in 1914, "Asia was the "fountain" of the "most destructive pestilence" in recorded history' (Shah, 2001, 258) - a persistent 'yellow peril' that the Covid-19 outbreak in Wuhan seemed to confirm.

Indeed, the new pandemic was not the first time that the public feared the transport of disease; the idea that plague came from other countries, brought by commercial ships and trains or by people carried by such transport, has a long genealogy (Molina, 2006, 86). Authorities claimed that an especially deadly smallpox arrived from China; local officials instituted quarantines of passenger ships much like was found with cruise liners during the discovery and spread of Covid-19 (Shah, 2001, 86; Robles, 2020). Embarking at Ellis Island, Southern and Eastern Europeans, considered at the time as not quite white, feared being sent back; medical inspectors scrutinised their bodies for signs of trachoma as well as tuberculosis - the concern was that they would become a public charge, dependent on state support, as well as a host for microbes (Kraut, 1994). New York's public health investigators were not alone; those in cities worldwide saw in racial difference a vector for infection. A tendency toward disease among colonised peoples, European governors contended, interfered with imperial projects to modernise those presumed backward and impose Western notions of gender, the work ethic, and civic order (Anderson, 2006; Shah, 2001, 21; Kaplan, 1998; Rafael, 1995).

The deadly 1918 'Spanish' flu brought a rush to judgment. Denver officials, for example, blamed the culture of Italians for spreading illness. They charged that Italians not only ignored public health pronouncements but continued to visit indisposed relatives rather than maintain separation - an allegation lobbed against Latino/as a century later. Disproportionate deaths from the 1918-1919 flu were among those immigrants living in crowded conditions who had to go out to work. These individuals were already malnourished and, as former peasants, had less previous exposure to similar viruses. Many were young adults, the demographic profile of the majority who died (Kraut, 2010; Reyes-Velarde, 2020).

Similar discourses framed newly-freed Black men and women as germ transmitters to white homes in the South and during the Great Migration to other regions of the country. The domestic servant, the belief went, would contaminate the white home, especially from syphilis (Hunter, 1997; May, 2011, 165-172; Urban, 2017). This unease with the intimate labour of the servant, whether Black women or Chinese 'houseboys', denied the dangers awaiting the worker who entered domestic workplaces where she or he could be exposed to sickness (Urban, 2017). Instead, the public fixated on the hazards from racial others: it envisioned laundries as superspreaders of tuberculosis and other airborne ailments from the supposed "practice of Chinese workers preparing clothes for ironing by spraying water from their mouths onto the clothes' (Shah, 2001, 98). Images of sweatshop labour conveying germs to unwitting consumers of tenement-made goods encompassed Eastern European immigrants, especially Jews, in New York City, no less than Chinese, Filipino/a, and other Asian workers on the West coast and, a century later, women in the Global 
South at the bottom of commodity supply chains who sewed cheap fashion for wealthier markets (Shah, 2001, 232-233; Boris, 1994).

Historians Nayan Shah and Natalia Molina have illuminated the late nineteenth and early twentieth century designation of Chinatowns and barrios as 'rotten spot[s]' that, as a Los Angeles's health officer put it, poison 'the air we breathe and...the water we drink' (Molina, 2006, 1). Doctors and journalists crafted voyeuristic accounts of Chinatown as exotic, dissipated, and unnatural. They dwelled on the sights and smells, including cloaks and queues of men judged as unmanly. They compared those residing in basements and other darkened areas to animals, carriers of disease like rats and pigs. Like migrant workers elsewhere crammed into singlesex housing, including present-day employer-provided barracks, Chinese men suffered from poor ventilation and inadequate sanitation (Fernandez, 2020; Shah, 2001; White, 2014). Justification for public health intervention came from assessment of environmental conditions that sensationalised 'dormitory pens' without adequate ventilation or waste disposal as a product of 'the moral degradation of opium smoking, gambling, and prostitution' rather than the results of discriminatory housing (Shah, 2001, 52-53). Solutions focused on the worker rather than the conditions they found themselves subject to. Thus, an 1854 investigation in San Francisco recommended 'removing from our midst the germs of pestilence' by eliminating Chinese labourers (Shah, 2001, 41). Along with most cities, San Francisco had not yet developed an adequate infrastructure for population growth, which had much to do with the overflowing of waste (Shah, 2001, 73-76).

Migrants defied norms of respectability. Such understandings hinged on being part of heteronormative families. Most Chinese men were 'bachelors', lacking the wealth to bring a wife into the country to compensate for a scarcity of available marriage partners following barriers enacted by the Chinese Exclusion Act of 1882 . They practiced what Shah calls queer domesticities, arrangements that included all male living groups but also female-headed households networked together (Shah, $2001,110)$. The turn to commercialized sex or same-sex relations brought opprobrium and fear of further contagion, including venereal disease and leprosy to be passed to white families by domestic servants as well as prostitutes.

Powerful racial labelling encouraged unequal treatment of those castigated as health risks. There was a discrimination loop, with health policy based on stereotypical distinctions reinforcing racial difference. Los Angeles passed ordinances to contain street vending, a means of Chinese livelihood. Other measures forced launderers to petition for remaining in newly-zoned residential areas. Only intervention from the Chinese Council and the merchant-run Chinese Six Companies led to a temporary reprieve from this burdensome regulation (Molina, 2006, 31-43). In seeking office, politicians weaponised 'discourses of racial hygiene', as Shah puts it. Particularly effective were the xenophobic rants of the Workingmen's Party of California in the period right before Chinese Exclusion (Shah, 2001, 55; Saxton, 1971).

Economic health and public health thus became intertwined with the expansion of cities. That the Chinese threatened the health of white city dwellers justified levelling Chinatown; that white business interests owned the property that Chinese 
inhabited meant that Chinatown remained standing as a potent symbol of pestilence which the powerful could rely on to foster economic and social discrimination. During epidemics, business had multiple interests, acting in contradictory ways; some quickly reduced hours while others, like in 2020, resisted shutdowns (Webster, 2020). The actuality was always far more complex than the rhetoric. Removal meant hospitalisation outside of the city. Rather than pay for treating Chinese in public hospitals by using a state tax on port arrivals passed for such purposes, those who fell ill had to rely on the philanthropy of 'respectable' co-ethnics - the kind of mutual aid still compensating for exclusion from public help (Shah, 2001, 43-44).

By the turn of the century, the San Francisco Board of Health began to eliminate substandard housing in Chinatown by expanding surveillance to rid the city of 'nuisances' (Shah, 2001, 96-97). Then it was hit with a bout of bubonic plague in 1900. The city quarantined the entire Chinese section of the city, targeting those deemed most likely to become infected rather than eliminating rodent carriers of the disease. Resembling the reaction of the Trump administration, businessmen and politicians worried about the economic consequences of this partial 'shut-down' rather than about trampling the rights of the Chinese, who in turn resisted inoculation with an unproven vaccine and rejected the diagnosis of plague. Recent migrants and settled immigrants alike were suspicious of public health pronouncements, believing that the authorities were out to poison them through vaccination. The courts sided with Chinese merchant plaintiffs in determining that such a district-wide quarantine overstepped the police powers of the state, but deaths continued until new elected officials undertook effective sanitary management, including demolition of condemned buildings, that then led to renewed business confidence. It took 4 years to quell the epidemic. By the next one, scientists understood the causes more fully as they exhorted the general public to clean their environs to get rid of rats that carried this scourge. Nonetheless, the association of disease with the Chinese immigrant worker persisted (Shah, 2001, 162-209).

The Chinese Exclusion Act reminds us that racialised immigrant restrictions developed to curtail populations, while allowing those with assets, such as merchants, their wives, and children, to enter (Lee, 2003). It further prohibited naturalisation or the obtaining of citizenship among those already in the US. The Chinese were not the only targets of immigration restriction. From the first naturalisation act in 1790 that limited potential citizenship to whites only, US immigration policy embedded racialised gendered assumptions. Treatment of the Chinese illustrates how these measures interfered with family formation, as with the 1875 Page Law that excluded Asian women 'imported' for prostitution and the Exclusion Act that made exceptions for elites. With the 1917 literacy act and the quota acts of the 1920s, lawmakers sought to lessen, if not end, the entry of Eastern and Southern Europeans, like Italians and Russian Jews - though loopholes existed for citizens to bring in domestic servants. While 1920s national quota acts disproportionately admitted Northern Europeans, there was no explicit bar to Mexicans or other migrants from the Americas. It was believed that they would return home after earning dollars after a season's labour (Gardner, 2005; Luibhéid, 2002). 
Like the Chinese, Mexican immigrants, often disproportionately male, faced blame for deadly outbreaks due to crowded and filthy living conditions. Declared one New Orleans doctor, '[E]very individual hailing from Mexico should be regarded as potentially pathogenic' (Molina, 2006, 63). Thought to be temporary sojourners even though some families dated their presence to before the annexation of California, Mexicans had become a primary labour force in Los Angeles by the second decade of the twentieth century. No laws restricted their arrival in contrast to Chinese exclusion and the 1907 Gentleman's Agreement with Japan. California 'Cubic Air Acts' and bars on Japanese land ownership further curtailed Asian migration (Molina, 2006, 9, 55). Mexicans, it was believed, were not the economic threat posed by 'entrepreneurial' Japanese farmers, who crossed gender norms by sending their women into the fields. Racial science designated Mexicans as physiologically suited for stoop labour.

Biopolitics could cut more than one way. On the one hand, authorities attempted to improve Mexican health for the benefit of the white community. Border crossing at El Paso, Texas, subjected second-class travellers to delousing and vaccination (Molina, 2006, 60). Typhus cases near Los Angeles in 1916 led the local health department to 'campaign against filth and lack of personal hygiene' in Mexican 'villages' and railroad worker camps (Molina, 2006, 61-62). Officials sought to 'enforce bodily cleanliness', including delousing Mexican school children (Molina, 2006, 64). Despite evidence of substandard workplace housing, the Board of Health would fix the behaviour of those subject to company housing, forcing them to undergo disinfectant baths under a military-like supervision. New hires had to be quarantined to curtail any outbreaks. All of this intervention was to protect the larger, white community. While not subject to policing, with Covid-19 exposed workers were to self-quarantine for the benefit of the dominant society.

A complaint conveyed to the Mexican consul prefigures worker protest a century later. Newly arrived railworkers explained, 'This wage they set is not enough for the nourishment of one person. Health comes from this and these precautions are the basis for achieving sanitation... What we need is liberty and the opportunity to achieve it. We need a bathroom in each section of camp and that the toilets that are now next to the sleeping quarters be moved'. They added, 'The Mexican race is not different form the American race and one should not think that disease takes hold in only our bodies. We are all human and they should not apply this procedure [delousing baths] only to Mexicans' (Molina, 2006, 67). The racialisation of epidemics, however, led to selective intervention, so that the porousness of the border tightened by using mandatory health inspections. Subsequent 'clean-up' campaigns served as projects in Americanisation to maintain a low-waged workforce (Molina, 2006, 71-73). Other quarantines, as against bubonic and pneumonic plague in 1924, sealed off neighbourhoods inhabited by Mexicans but let industrial workers leave for jobs outside the cordoned area (Molina, 2006, 85).

Los Angeles Anglos began to recognise, as would their counterparts during Covid-19, that immigrant workers 'are here to say...but whether we are to let them live here in unhealthy conditions and ruin the appearance of our cities depends on [us]' (Molina, 2006, 75). Nonetheless, urban health centres established to improve 
Mexican health focused not on prevention of illness but rather on lowering infant mortality. Compensating for a supposed inadequacy of Mexican women proved easier than raising wages or providing healthful workspaces and homes. But the lack of quality services tended to reinforce existing inequalities through differential treatment much as the rail workers earlier had complained. Available services at best encompassed urban areas and rarely covered waste disposal and water availability on the periphery or outside of the city. Social workers labelled Mexicans, as sociologist Cybelle Fox has documented, 'an especially dependent and undeserving group' (Fox, 2012, 73).

Such thinking that Mexicans as non-citizens deserved no public relief set the stage for mass deportation during the early 1930s. Congress had authorised the Border Patrol in 1924 to enforce the National Origins Act of that year (Hernandez, 2010). When the Great Depression hit, Mexicans turned into undesirable surplus people. Of some 2.5 million in 1932, it was estimated that 2 million lacked work (Molina, 2006, 126). They became a 'brown peril' not only because of their culture but also due to perceptions of their biology. Eugenic thinking led officials to seek to rid them from the body politic. Despite growth in communicable disease, previously available public health clinics were to refuse treatment without payment. Officials rejected public aid because it was thought to merely subsidise big agriculture and other employers - and because Mexicans were undeserving 'diseased' others (Molina, 2006, 118-126, 129; Fox, 2012, 80). Molina concludes, 'severe financial constraints and widely accepted constructions of Mexicans as a large, diseased, charity-seeking population combined to make deportations and so-called voluntary repatriations a cornerstone of immigration policy' (Molina, 2006, 136). Los Angeles's charity hospital turned into a site for capture as it cooperated with deportation agents, reinforcing the reluctance of immigrants to seek medical attention that appeared again during the 2020 pandemic when undocumented workers stayed away from doctors (Chishti \& Pierce, 2020).

Public health and other government agents skirted the law, manoeuvring around the formal federal hearings that were to be used against those determined to have become a public charge within 5 years of arrival. Los Angeles went straight to deportation (Fox, 2010, 124-135). The cities of Detroit, Michigan, and Gary, Indiana, also sponsored removal, abetted by local social workers, when the auto factories and steel mills laid off workers. Nationally, of the 54,000 people deported between 1930-1932, 44\% were Mexicans, while another 44,000 voluntarily exited, euphemistically called repatriation. By 1935, up to $40 \%$ of the Mexican population had left (Fox, 2010, 127, 182-187). The combination of racial stigmatisation and economic crisis pushed migrant workers out of the country even as the numbers seeking entrance plummeted, a pattern similar to declines during Trump's presidency with its active discouragement of immigration and ending of asylum for those stuck at the Mexican border (Chishti \& Pierce, 2020; Friedman, 2020).

Rather than assist migrant workers, the New Deal built into its overhaul of social provision and nationalising of labour standards distinctions between citizens and non-citizens, men and women, whites and other racialised groups, and the old and young. The vast majority of African American, Mexican American, and immigrant 
women could neither rely on their men's access or their own labour histories to be covered by unemployment insurance or pensions and found themselves forced to accept either low-waged jobs or try to qualify for public assistance. There was no mandate to provide any aid to those not citizens in the first place. Citizen migrant workers, who moved from state to state, could access New Deal programmes through special camps for transients, but after 1935 state residency requirements restricted eligibility. Some landowners relied on government relief programmes to carry over hirelings until the next season; in this regard they prefigured the behaviour of some employers in 2020 who wished to maintain their workforce. Still, during the Great Depression, local elites discriminated against Blacks and Mexicans in distributing relief. Landlords also replaced Anglo white tenants with African Americans and Mexicans, whom they forced to sign away government payments as a condition of employment. Such labour practices intensified the racialisation of farm labour and lowered standards of living, fanning anti-immigration and antiBlack sentiments among white and Anglo workers in the South and Southwest (Boris, 2008).

To meet agricultural labour shortages during World War II, the Bracero Program emerged as a foreign guestworker programme facilitated through cooperation with Mexico. Through its auspices, local landowners would contract fieldhands. It brought Mexican nationals to California, Arizona, and southwestern fields and Caribbean migrants to the East Coast, including Florida (Hahamovitch, 1997, 2011). At border stations men underwent invasive screenings; one former 'bracero', as they were designated, recalled, 'Supposedly we were flea-bitten and germridden'. As historian Deborah Cohen concludes, 'they crossed at a time when parasites signified dirt, disease, and a life without access to running water...they were flagged as potential carriers of disease and, in the process, linked to racialized poverty' (Cohen, 2011, 99). After reauthorisation in 1946, Congress removed such guestworkers from social assistance and state protection by privatising their living arrangements. The 'bracero' without a contract became a 'wetback' vulnerable to deportation for speaking up, striking, or malingering on the job. When skipping out of contracts, they lost the protection of Mexican consuls. These officials served as their bargaining agents until 1954 amendments to the Migrant Labor Agreement undercut any Mexican control over labour supply and, hence, working conditions. Only after a coalition of liberals and trade unions won the end of the programme in 1964 were agricultural workers able to gain inclusion under the nation's wage and hour law (Boris, 2008).

Other migrants were not as lucky. Household workers remained outside of labour laws into the twenty-first century, including the 1970 Occupational Safety and Health Act. Home care aides only gained wage and hour protections during the Obama administration. Private household workers still have no right to collective bargaining (Boris, 2019). The Personal Responsibility and Work Opportunity Act of 1996, which reformed 'welfare', left to the states whether to extend Temporary Aid to Needy Families to immigrants, but again barred new arrivals from receiving monies for 5 years (Mink, 1998, 62-63, 150n28). The accompanying Illegal Immigration Reform and Immigrant Responsibility Act of 1996 incorporated two significant 
practices: it required applicants for visas to provide proof of vaccination for communicable diseases and mandated that family sponsors certify their ability to support the entrant least they become a burden on local governments (Fragomen Jr, 1997; Fujiwara, 2008). The racialised politics of exclusion persisted when it came to placing migrants under protective laws.

\subsection{Cruel Treatments: Detained Migrants and Essential Workers}

In keeping with its white nationalism, the Trump administration initially sought to seal the nation's borders from the pandemic as if only non-citizens and visitors could carry the virus from abroad. Beginning in late January through March 2020, it banned entry of non-citizens from China, then Iran, and finally Europe. It used the virus as an opportunity to intensify its anti-immigration stance by ending Temporary Protected Status for Haitians, El Salvadorans, and others who had fled to the US in the midst of civil unrest in their countries decades before, while it halted granting asylum to new seekers. Drawing on the Tariff Act of 1930, the US Customs and Border Control closed the border with Canada as well as the one with Mexico, particularly impacting Central Americans left waiting in Mexico. Announced the Director of the Centers for Disease Control and Prevention (CDC): 'The danger to the public health that results from the introduction of such persons into congregate settings at or near the borders' justified closure'. The US, however, was hardly alone, with nearly 200 other countries imposing restrictions at that time and the UN High Commissioner for Refugees suspending resettlement of refugees (Chishti \& Pierce, 2020). In deporting Guatemalans and other Central Americans, through some 180 flights from virus 'hotspots' in Texas, Arizona, California, and Florida, the US exported Covid-19. Eleven of 15 countries from the Americas reported deportees arrived testing positive. In moving detainees, it also spread Covid-19 within the country between detention facilities (Kerwin, 2020, 4-5; International Rescue Committee, 2020; Albaladejo, 2020).

US Immigration and Customs Enforcement (ICE) continued to detain undocumented immigrants, terrorising neighbourhoods through randomised raids even after prioritising the round-up of criminals and 'safety' risks. As during the Great Depression, the government sought to target undesirable immigrants by using health services and benefits to identify them. A new public-charge rule made use of public benefits a reason to deny immigrants the green card that allows them to legally work (Chishti \& Pierce, 2020). Treatment for Covid-19 was to be an exemption, but the new rule increased the precarity of immigrants who feared to take advantage of health and other benefits for children, like the Supplemental Nutrition Assistance Program (SNAP). Moreover, relief measures in Spring and early Summer 2020 excluded from tax rebates, unemployment supplements, or other aid some four million immigrant workers without legal status but who had individual taxpayer 
identification numbers (Chishti \& Pierce, 2020; Covid-19 Conference Call, 2020). They paid into a system without receiving any relief.

The numbers in detention camps grew in contrast to other countries. The United Kingdom released one-third of its detainees out of recognition that close quarters turned such facilities into petri dishes for viral spread. Italy, Switzerland, and Zambia reduced numbers of migrant detainees (Kerwin, 2020, 25-26). The crowded and under-resourced US holding stations and detention jails, sometimes packing 100 men into a room, had few medical personnel. They already had proven congenial for outbreaks of other contagious conditions, like flu and measles. Covid-19 appeared in them as well, ranging from a public New Jersey ICE detention centre to privately-run Texas ones (Chishti \& Pierce, 2020; International Rescue Committee, 2020). ICE delayed testing. It only made available partial results. Yet even these showed that half of those tested between April and early June were positive. Since facilities only tested symptomatic people, the actual numbers could have been 15 times greater. While over Spring 2020 numbers of detained individuals in 200 centres dropped from 29,675 to 24,713, positive tests plateaued and then climbed over the summer (Jawetz \& Svajlenka, 2020; Kerwin, 2020).

During local surges, detainees remained 'sitting ducks', as the American Civil Liberties Union referred to them (La Gorce, 2020). By August 2020, ICE counted nearly 4000 cases, with one-quarter of those infected still in custody (International Rescue Committee, 2020). In August, fuelled by transfers from Florida and Arizona, the Farmville, Virginia Detention Center run by the private Immigration Centers of America had a $90 \%$ infection rate among its nearly 300 -person population (Schwenk, 2020). The Eloy Detention Center in Arizona, for another example, saw a 'tenfold' rise in cases in a three-week period in June. Not only was social distancing impossible, but sanitiser and soap were in short supply and access to showers irregular. Agents went about maskless. Detainees at the La Palma Correctional Center, also in Arizona, complained of being 'forced to clean medical wards and common areas without enough protective gear'. Reported a transgender migrant, a group considered 'medically vulnerable' (Castro, 2020) and susceptible to violence at home, during migration, and in detention: 'They have told us that if we feel bad, they will send us to a doctor that moment...but it's a lie...I always feel like I'm between life and death' (Reznick, 2020).

In these circumstances, staff become infected, bringing the virus into surrounding communities and to other facilities during inmate transfers. The for-profit LaSalle Corporation, with eight centres in southern states, faced charges of withholding 'personal protective equipment [PPE] from staff and detainees, dismissed positive Covid-19 tests results, and ignored symptoms' (Olivares \& Washington, 2020). Yet ICE kept no records of private prison staff, even though in Texas nine out of ten centres operated by contractors had cases by early May (Reznick, 2020; Kerwin, 2020, 5-7).

A whistleblower complaint from a former employee lodged against a particularly notorious centre in Irwin, Georgia, claimed that Spanish-speaking women received without their consent hysterectomies from a local gynaecologist, an action likened to 'an Experimental Concentration Camp'. Migrant women subject to forced 
sterilisation evoked past eugenic practices as well as a gendered punishment for daring to cross the border. With 57 women claiming pressure to undergo unnecessary treatment or actually suffering such abuse, advocates wanted 'accountability for ICE and the private prison corporation because these are the entities that are holding these women' without concern for their health or safety. With the pandemic, their previously ignored mistreatment had a hearing. It came to symbolise abuse of human rights and women's bodily autonomy, a gendered harm previously associated with other authoritarian confinements (Shen, 2020; Washington \& Olivares, 2020).

Despite shortage of PPE, desperately needed by medical workers at detention camps as well as hospitals and nursing homes, the Trump administration was reluctant to invoke the Defense Production Act of 1950. This Korean War measure authorised the President 'to direct private companies to prioritize orders from the federal government' (Siripurapu, 2020). He would issue some weak executive orders relating to hoarding and the production of essential ventilators and N95 masks, made after companies like GM already announced such production. In contrast, Trump most publicly deployed this authority 'to order meat processing plants to stay open' despite major outbreaks of Covid-19 in an industry where immigrant workers had found a niche (Gangitano, 2020). He would sustain the food supply for meat eaters despite risks to its workforce. When Trump acted in late April 2020, at least 20 workers had died and 5000 had been exposed, though the actual numbers were in the thousands (Trumka, 2020). Absenteeism had reached 50\% in North Carolina, Kansas, and Nebraska plants (Grabell \& Yeung, 2020). According to the CDC, the credibility of which suffered under Trump administration political interference, meat processing outbreaks by early July in facilities reporting cases occurred in 23 states and 239 plants, amounting to over 16,000 infections, 9\% of the workforce, with a death rate of $.5 \%$ (general death rates include more elderly people and thus were slightly higher at six times that of the flu). Nearly $90 \%$ of the infected were racial or ethnic minorities, the vast majority of the workforce to begin with (Tate, 2020; Waltenburg et al., 2020).

Indeed, the racial division of labour led to Covid-19's disproportionate impact on African Americans, Latina/o/xs, and immigrants. The resulting shutdown forced immigrants out of work in large numbers: in California, immigrants had held one out of four lost jobs, with undocumented women doing 'non-essential' service labour accounting for one out of three of the unemployed (Flores et al., 2020). They laboured in sectors hard hit by the virus. Immigrants composed some $17 \%$ of healthcare workers, while those without work permits crowded into related frontline jobs. One 2018 estimate from census data found almost $40 \%$ of health support workers to be undocumented: 'from nursing assistants and home health aides to housekeepers, receptionists, janitors, and cooks'. Filipino/as made up 30\% of immigrant nurses and suffered from a disproportionate 'toll' from Covid-19 in Canada and Britain as well (Tungohan, 2020). At the height of the epidemic in New York City, Corona, Queens, a hugely immigrant neighbourhood, generated the greatest number of known cases; 'Hispanic immigrants' made up 34\% of deaths even though they were only $29 \%$ of the population; Blacks, at $22 \%$ of the population, constituted $28 \%$ of 
the deaths (Persaud, 2020). Percentages from Iowa, Oregon, Florida, and California were similar or worse (Jordan \& Oppel Jr, 2020). Like a century ago, 'closeknit...family ties' were blamed for spreading the infection - along with overcrowded and poor housing conditions, especially among California's Latina/o/x poor (Cimni \& Botts, 2020; Reyes-Velarde, 2020).

Immigrants and refugees for years had composed the packinghouse workforce: Bhutanese, Mayans, various Latina/o/x, North Africans, Burmese, Cubans, Romanians, and Chinese (Grabell, 2017). They had become essential workers, called 'critical', but as an undocumented Guatemalan toiling at Koch Foods in Mississippi queried, 'if they have a big need for all of the workers, ... why aren't they worried about us?' Like many other essential workers, meatpackers could not practice social distancing. The very organisation of the labour process for maximum efficiency got in the way. They worked 'shoulder to shoulder' at a fast pace to keep the line moving. On top of that, despite the protests of unions weakened by the labour law and growth in non-union operations, workers lacked health insurance and sick pay, so they went to work sick. To do otherwise risked being fired (Grabell, 2020).

Migrant farmworkers faced similar circumstances, especially those packing fruit in warehouses. About 50\% of hired agricultural workers were undocumented (Schloredt, 2020). For the rest, growers had begun to rely on bringing in hands through use of H-2A visas. These temporary cards were tied to specific employers much like the Bracero Program of old, deployed to mitigate labour shortages with guestworkers. The processing of such visas went on 'as a national security priority' after a short hiatus in March (Jarvis, 2020). Under this system, employers were responsible for housing and transporting workers, while paying at least the minimum wage. In fact, recruiters still charged migrants for travel. Workers thus fell into debt; their dependency made it more difficult to protest unsafe conditions and wage theft, leading some to refer to the $\mathrm{H}-2 \mathrm{~A}$ visa as a "modern system of indentured servitude' (ibid.).

Social distancing again was impossible. Packed vans delivered workers, mostly men, to the fields. Tents and shared housing kept labourers close to each other. While Oregon banned bunk beds, growers housed larger cohorts of labourers together than allowed under state regulations (ibid.). In Pennsylvania, with over 4000 seasonal guestworkers, even farm labour camps with permits were overcrowded; the state issued only recommendations rather than promulgate requirements with penalties. The state Occupational Safety and Health Administration (OSHA) had stopped doing inspections (Fernandez, 2020). Farmworkers, some 3\% of the population, accounted for $20 \%$ of the cases in Washington state, which had no ban on bunkhouses (Jarvis, 2020). In Florida, the area surrounding Immokalee turned into a virus epicentre, with a $36 \%$ positivity rate by early June when the state was just under 6\%; its Latino/a/x and Haitian workforce would follow the crops up the coast, and few were tested beforehand. Reported a volunteer physician, 'Workers have to get their own masks, so maybe three out of 20 people have masks on and there's pressure not to wear them - it's not a "tough" thing to do'. Neither did testers inquire about contacts or provide instructions on self-isolation, a difficult task when 
nine people of various ages, some strangers to each other, crowded into a trailer built for lower occupancy (Reiley, 2020).

Imprecise record-keeping, that noted place of death but not origin of infection, compounded the problem of faraway hospitals, lack of health care, and pressure to continue working. The local health department offered exposed workers full accommodations: free lodging, with bathrooms and kitchenettes and necessities like hand sanitiser and groceries. But it unsurprisingly noted, 'We can't pay them or supplement their income... we know people want to provide for their families, often sending money back to support people where they are from'. Pressure from growers added to the reluctance of migrants to leave the fields even if they tested positive (Reiley, 2020).

Domestic workers faced their own set of pressures during the pandemic. Disproportionately immigrants and women of colour compared to other occupations, some worked legally but resided within mixed-status households, with family and roommates undocumented. They needed the income to live here but also to send remittances to relatives abroad. Few employers, whether for private residences or nursing homes, provided PPE. Not wanting to leave their clients without care, some both grappled with possible exposure to pathogens and feared carrying the virus between households or from nursing homes which housed their 'consumer'. 'I care for the elderly because I consider this a noble profession, and not everyone can be a caregiver', explained a 60-year-old migrant from the Philippines who had been in the US for about a decade. Yet she worried about infecting the 90-year-old woman in her charge. 'I take a bus to and from work, which is risky in terms of spreading germs, but I cannot afford to take Uber', she confessed (Bapat, 2020).

Other workers, like a 39-year-old Mexican immigrant in northern California, found themselves fired. 'I understand that my clients don't want me to come to their homes because they are worried about being in contact with another human being... I am worried about the same thing', she told a reporter in April 2020 (ibid.). After a nanny in New York City from Antigua verbalised fear about catching the virus in March, she lost her job with 'no severance pay or nothing' and was without work 3 months later. Indeed, in early April 2020 the National Domestic Worker Alliance found two-thirds of respondents could not count on clients hiring them back; by May the unemployed had risen to 70\% (Brooks, 2020; Wolfe, 2020). The same percentage of domestic workers in Latin American and the Caribbean, many of whom were from Indigenous groups, also suffered from government measures to contain the outbreak. Similar to the US, 'In addition to the spectre of unemployment, informality, low social protection coverage and the lack of written contracts in many cases - prevent them from accessing the aid established by Governments', reported the International Labour Organization (United Nations, 2020). For those in Argentina, Afghanistan, Indonesia, and worldwide, no work also meant no pay. As the International Domestic Workers Federation noted, 'the logic of the quarantine assumes the availability of accommodation, means of sustenance, and safety of households', conditions unobtainable by domestic workers, especially migrants (IDWF, 2020; Lewis et al., 2020). 


\subsection{Resiliency}

Despite exclusion from state-sponsored relief during the pandemic, migrant workers - whether labouring in homes, fields, warehouses, or medical facilities - continued to organise. They confronted their circumstances through strikes, mutual aid, and demands on the state as well as employers. Like immigrant workers more than a century ago, they banded together to seek recognition and rights, dignity and justice. Unlike the past, they had new tools of social media to spread grievances and publicise protests.

Lack of safety for grocery clerks, bus and truck drivers, fast-food servers, Instacart and other delivery app gig workers, sanitation employees, Amazon distribution warehouse packers, and the entire agricultural food chain sparked wildcat strikes among US-born and migrant workers alike - but with more peril for those here as guestworkers (Brecher, 2020) Fruit packers and pickers struck. In the Yakima Valley of Washington State, hundreds of mostly Mexican labourers walked off the job demanding hazard pay and safer workplaces. Those at Roche Fruit Company won $\$ 100$ per week extra, what the company called 'gratitude pay' in a mystification that defined the increase as temporary. These strikes, however, were as much about protecting 'ourselves and our families'. According to Familias Unidas por la Justicia, women led these multigenerational and multiracial strikes (Bacon, 2020).

Immigrant communities turned to mutual aid and organised private relief, as the San Francisco Chinese had done over a century before. With undocumented workers in restaurants and other service industries especially hard hit by shutdowns and cut off from government monies, they depended on local fund drives. Despite the best of efforts, these proved inadequate, but so did public monies. The 805 Undocufund in Santa Barbara and Ventura counties, California, first developed to aid immigrant workers during wildfires; it started up again during the pandemic when layoffs grew. Despite contributions from citizen workers, some of whom donated government stimulus checks as 'acts of solidarity', 7000 people were on a waitlist by late May 2020. The $\$ 75$ million appropriated by California's Governor to relieve undocumented people would only reach about one-quarter of them, who collectively paid $\$ 3$ billion in taxes, advocates noted (Osgood, 2020).

Mutual aid reflected the belief that domestic workers should be able to stay home when sick or when their family needs them. In the Bay area, Los Angeles, and San Diego, various Philippine workers centres distributed 'care boxes' full of food and other items to help members get by. Other workers centres, like CASA in Maryland, Virginia, and Pennsylvania, provided food, raised a solidarity fund, and campaigned around rent cancellation (Covid-19 Conference Call, 2020). The National Domestic Workers Alliance established a Coronavirus Care fund, with a goal to raise $\$ 4$ million dollars, to distribute emergency assistance of $\$ 400$. The group administered the monies through Alia, its online platform through which employers could contribute the equivalent of benefits for paid time off and other uses (Poo, 2020).

Activists in solidarity with migrants called for state protection. Over a hundred organizations petitioned Maryland's Republican Governor Larry Hogan to issue 
emergency orders for mandatory PPE for farmworkers, poultry and seafood workers in June 2020 and continued to pressure for action into the Fall (Marylanders for Food \& Farm Worker Protection, 2020; Migrant Clinicians Network, 2020). Other states, notably Virginia, enacted emergency standards for such vulnerable frontline workers, mostly migrants from the Americas. As its Democratic Governor Ralph Northam announced, 'In the face of federal inaction, Virginia has stepped up to protect workers from Covid-19, creating the nation's first enforceable workplace safety requirements' (Berkowitz, 2020; Garcia-Navarro \& Silva, 2020). Domestic Workers mobilised in California to remove the exclusion of domestic workers from the state's occupational health and safety regulations, which was modelled after the federal law. Allen, from the Los Angeles Pilipino Worker Center, testified, 'caregivers like me... are on the frontlines, in close contact with people who are most vulnerable'. While those employed by nursing homes and hospitals 'have the right to protective equipment, training and information,' home care workers had no such guarantees. Cal/OSHA operates by the exception that individual employers who pay for domestic and household tasks in their own dwellings do not have to abide by its regulations. These workers not only faced infection, but they lacked protection from the smoke and soot from wildfires, damage from which their employers expected them to clean up (CDWC, 2020). In vetoing a bill to rectify the exclusion, passed overwhelmingly by the legislature in the midst of wildfires and the pandemic, Governor Gavin Newsom, a Democrat, ignored the establishment of a stakeholder commission to develop regulations for the sector and the educative role of Cal/OSHA. Instead he relied on old canards by claiming that the home was not like other workplaces and that its inhabitants lacked the 'expertise to comply' (Newsom, 2020). Domestic workers vowed to continue their struggle for health and safety on the job; they gained an amended bill to establish voluntary guidelines in September 2021.

\subsection{Concluding Remarks}

Migrants to the US, whether undocumented or permitted, found themselves particularly vilified after Donald Trump became president. However, these years were not unique in the long history of a country that once referred to itself as 'a nation of nations' (Marzio, 1976). To generate a genealogy of racialised vulnerability, this chapter has explored a set of major responses to migrant workers in the past. It has shown that the association of the non-citizen with the racial other and both with epidemic infection led to public policies, in the local as well as national realm, that reinforced discrimination and enhanced precarity. A century later the nation was relying on similar measures of quarantine and exclusion. In the face of new viruses, it remained easier to target migrants and undocumented immigrants than force citizens to take public health precautions.

Driving the racialisation of public health were the forces central to the US political economy. A nation founded on settler colonialism and racial capitalism, the US sorted people by race and then justified inequality through affixing justifying 
attributes. Dirt and disease adhered to those deemed as racial others, with whiteness associated with cleanliness and thus healthfulness. Low wages, crowded housing, and economic, political, and social discrimination often led to poorer health outcomes, which in turn rationalised blaming migrants - and their race/ethnicity or national origins - instead of these precipitating living and working conditions that led to bodily harms.

In response to Covid-19, government actions - and inactions - illuminate the making of pandemics as a social and not merely biological or scientific phenomenon. Despite the odds, migrant workers attempted to refocus the discourse by speaking out and walking off. They engaged in self-help when the government refused support. In demanding basic health and safety, along with sustainable wages and decent working and living conditions, they insisted on recognition and respect. In puncturing the hypocrisy behind rhetorics of essential workers as heroes, they demanded protection that belonged to all people and not only citizens.

\section{References}

Albaladejo, A. (2020). Death, miscarriage and COVID-19: Inside ICE Air's history of medical neglect. Capital \& Main, 19 September. https://capitalandmain.com/ death-miscarriage-and-covid-19-inside-ice-airs-history-of-medical-neglect-0919

Anderson, W. (2006). Colonial pathologies: American tropical medicine, race, and hygiene in the Philippines. Duke University Press.

Bacon, D. (2020). Hundreds of Apple workers on strike in Washington. Labor Notes, 16 May. https://portside.org/2020-05-18/hundreds-apple-workers-strike-washington

Bapat, S. (2020). Who cares for care workers during the pandemic? Truthout, 7 April. https:// truthout.org/articles/who-cares-for-care-workers-during-the-pandemic/

Berkowitz, D. (2020). Which states and cities have adopted comprehensive COVID-19 worker protections? National Employment Law Project Blog, 10 August. https://www.nelp.org/blog/ which-states-cities-have-adopted-comprehensive-covid-19-worker-protections/

Boris, E. (1994). Home to work: Motherhood and the politics of industrial homework in the United States. Cambridge University Press.

Boris, E. (2008). Labor's welfare state: Defining workers, constructing citizens. In C. Tomlins \& M. Grossberg (Eds.), Cambridge history of American Law (Vol. III, pp. 319-358). Cambridge University Press.

Boris, E. (2019). To live decently: New Deal labor standards, feminized work, and the fight for worker dignity. In G. Gerstle, N. Lichtenstein, \& A. O'Connor (Eds.), Beyond the new deal order: From the great depression to the great recession (pp. 93-109). University of Pennsylvania Press.

Brecher, J. (2020). Striking in the coronavirus depression. Labor Network for Sustainability, 14 September. https://portside.org/2020-09-14/striking-coronavirus-depression

Brooks, K. J. (2020). Domestic workers face low pay, no health coverage and COVID-19. Moneywatch, CBS News, 22 June. https://www.cbsnews.com/news/ domestic-workers-job-loss-coronavirus-pandemic-low-wages-health-insurance/

Castro, A. (2020). TLC, Ballard Spahr, \& Rapid Defense Network announce class action lawsuit to free all transgender people in ICE custody. Transgender Law Center, 23 April. https://transgenderlawcenter.org/archives/15791

CDWC (California Domestic Workers Coalition). (2020). Domestic workers celebrate the passage of the health and safety for all workers act through senate labor committee. Press Release, 15 
May. https://www.cadomesticworkers.org/news/domestic-workers-celebrate-passage-of-thehealth-and-safety-for-all-workers-act-through-senate-labor-committee/.

Chishti, M., \& Pierce, S. (2020). Crisis within a crisis: Immigration in the United States in a time of COVID-19. Migration Policy Institute, 26 March. https://www.migrationpolicy.org/article/ crisis-within-crisis-immigration-time-covid-19.

Cimni, K., \& Botts, J. (2020). Close quarters: California's overcrowded homes fuel spread of coronavirus among workers. CalMatters, 12 June. https://calmatters.org/projects/ overcrowded-housing-california-coronavirus-essential-worker/

Cohen, D. (2011). Braceros: Migrant citizens and transnational subjects in the postwar United States and Mexico. UNC Press.

Covid-19 Conference Call (Coronavirus and Its Impact on Workers Conference Call). (2020). Minutes. Kalmanovitz Initiative, Georgetown University, August 11, in author's possession.

De Loera-Brust, A. (2020). As the U.S. Exports Coronavirus, Trump blaming Mexicans. Foreign Policy, 14 July. https://foreignpolicy.com/2020/07/14/ as-the-u-s-exports-coronavirus-trump-is-blaming-mexicans/

Donaghue, E. (2020). 2,120 hate incidents against Asian Americans reported during coronavirus pandemic. CBS News, 2 July. https://www.cbsnews.com/news/ anti-asian-american-hate-incidents-up-racism/

Farley, R. (2020). Trump wrongly blames protests, Mexico for COVID-19 spread. FactCheck Posts, 23 July. https://www.factcheck.org/2020/07/ trump-wrongly-blames-protests-mexico-for-covid-19-spread/

Fernandez, C. (2020). Tight housing, lack of health care put migrant workers on Pa. farms at high risk for the coronavirus. WHYY News, 21 April. https://whyy.org/articles/tight-housing-lack-ofhealth-care-put-migrant-workers-on-pa-farms-at-high-risk-for-the-coronavirus/

Flores, E. O., Padilla, A., Karina, J., \& Qaiser, R. (2020). Massive job losses among non-citizens in California and the US (Policy Report). Community and Labor Center, University of California Merced, May. https://ssha.ucmerced.edu/sites/ssha.ucmerced.edu/files/documents/massive_ job_losses_5-22-2020.pdf

Fox, C. (2012). Three worlds of relief: Race, immigration, and the American welfare state from the progressive era to the new deal. Princeton University Press.

Fragomen, A. T., Jr. (1997). The Illegal Immigration Reform and Immigrant Responsibility Act of 1996: An overview. The International Migration Review, 32(2 Summer), 438-460.

Friedman, G. (2020). What do fewer immigrants coming to the U.S. mean for our economy and workforce? DeseretNews, 6 January. https://www.deseret.com/indepth/2020/1/6/21048887/ what-do-fewer-immigrants-coming-to-the-u-s-mean-for-our-economy-and-workforce

Fujiwara, L. (2008). Mothers without citizenship: Asian immigrant families and the consequences of welfare reform. University of Minnesota Press.

Gangitano, A. (2020). Trump uses defense production act to order meat processing plants to stay open. The Hill, 28 April. https://thehill.com/homenews/ administration/495175-trump-uses-defense-production-act-to-order-meat-processing-plants-to

Garcia-Navarro, L., \& Silva, C. (2020). Virginia poultry workers see victory in new COVID-19 protection rules. NPR, July 19. https://www.npr.org/2020/07/19/892757768/ virginia-workers-see-victory-in-covid-19-protection-rules

Gardner, M. (2005). The qualities of a citizen: Women, immigration, and citizenship, 1870-1965. Princeton University Press.

Grabell, M. (2017). Can low-wage industries survive without immigrants and refugees? ProPublica, 5 May. https://www.propublica.org/article/low-wage-industries-immigrants-and-refugees

Grabell, M. (2020). What happens if workers cutting up the nation's meat get sick? ProPublica, 28 March. https://www.propublica.org/article/ what-happens-if-workers-cutting-up-the-nations-meat-get-sick

Grabell, M., \& Yeung, B. (2020). Meatpacking companies dismissed years of warnings but now say nobody could have prepared for COVID-19. ProPublica, 20 August. https://www.propublica. 
org/article/meatpacking-companies-dismissed-years-of-warnings-but-now-say-nobody-couldhave-prepared-for-covid-19

Hahamovitch, C. (1997). The fruits of their labor: Atlantic coast farmworkers and the making of migrant poverty, 1870-1945. UNC Press.

Hahamovitch, C. (2011). No man's land: Jamaican guestworkers in America and the global history of deportable labor. Princeton University Press.

Hernandez, K. L. (2010). Migra! A history of the U.S. Border Patrol. University of California Press.

Hunter, T. (1997). To 'joy my freedom: Southern black women's lives and labors. Harvard University Press.

International Domestic Workers Federation (IDWF). (2020). The impact of COVID-19 on domestic workers and policy responses. 1 May.

International Rescue Committee. (2020). Covid-19 escalating in ICE detention centers as states hit highest daily records - and ICE deportation flights into Northern Triangle continue. Press Release, 3 August. https://www.rescue.org/press-release/ covid-19-escalating-ice-detention-centers-states-hit-highest-daily-records-and-ice

Jarvis, B. (2020). The scramble to pluck 24 billion cherries in eight weeks. The New York Times Magazine, 12 August. https://www.nytimes.com/2020/08/12/magazine/cherry-harvestworkers.html

Jawetz, T., \& Svajlenka, N. P. (2020). Data on the coronavirus outbreak in immigration detention offer more questions than answers. Center for American Progress, 16 June. https://www.americanprogress.org/issues/immigration/news/2020/06/16/486338/ data-coronavirus-outbreak-immigration-detention-offer-questions-answers/

Jordan, M., \& Oppel, R. A., Jr. (2020). For Latinos and Covid-19, doctors are seeing an 'Alarming' disparity. The New York Times, 7 May. https://www.nytimes.com/2020/05/07/us/coronaviruslatinos-disparity.html

Kaplan, A. (1998). Manifest domesticity. American Literature, 70(3 September), 581-606.

Kerwin, D. (2020). Immigrant detention and COVID-19; how a pandemic exploited and spread through the US immigrant detention system. Center for Migration Studies, August. https:// cmsny.org/wp-content/uploads/2020/08/CMS-Detention-COVID-Report-08-12-2020.pdf

Kraut, A. M. (2010). Immigration, ethnicity, and the pandemic. Public Health Reports, 125(Suppl 3), 123-133. https://www.ncbi.nlm.nih.gov/pmc/articles/PMC2862341/

Kraut, A. M. (1994). Silent travelers, germs, genes, and the "Immigrant Menace". Basic Books.

La Gorce, T. (2020). 'Everybody was sick': Inside an ICE detention center. New York Times, 15 May, updated 10 July. https://www.nytimes.com/2020/05/15/nyregion/coronavirus-icedetainees-immigrants.html

Lee, E. (2003). At America's gates: Chinese immigration during the exclusion era. UNC Press.

Lewis, E., et al. (2020). 'Invisible hands': How millions of domestic workers fare under COVID-19. Global Voices, 20 July. https://globalvoices.org/2020/07/20/ invisible-hands-how-millions-of-domestic-workers-fare-under-covid-19/

Luibhéid, E. (2002). Entry denied: Controlling sexuality at the border. University of Minnesota Press.

Marzio, P. (1976). A nation of nations. HarperCollins.

Marylanders for Food \& Farm Worker Protection. (2020). Take action call, 25 September. Author's possession.

May, V. (2011). Unprotected labor: Household workers, politics, and middle-class reform in New York, 1870-1940. UNC Press.

Migrant Clinicians Network. (2020). Call to action: Protect Maryland farmworkers from COVID-19. MCN News, 22 June.

Mink, G. (1990). Old labor and new immigrants in American political development: Union, party, and state, 1875-1920. Cornell University Press.

Mink, G. (1998). Welfare's end. Cornell University Press.

Molina, N. (2006). Fit to be citizens? Public health and race in Los Angeles, 1879-1939. University of California Press. 
Moloney, D. M. (2012). National insecurities: Immigrants and U.S. deportation policy since 1882. UNC Press.

Newsom, G. (2020). Letter to the members of the California State Senate on SB1257. 29 September. https://www.gov.ca.gov/wp-content/uploads/2020/09/SB-1257.pdf

Olivares, J., \& Washington, J. (2020). 'A silent pandemic': Nurse at ice facility blows the whistle on coronavirus dangers. The Intercept, 14 September. https://theintercept.com/2020/09/14/ ice-detention-center-nurse-whistleblower/

Osgood, B. (2020). Santa Barbara's undocumented community in desperate need of help. Santa Barbara Independent, 22 May. https://www.independent.com/2020/05/22/ santa-barbaras-undocumented-community-in-desperate-need-of-help/?utm_ source $=$ Indy+Today\&utm_campaign $=$ b21c420b1d-Indy+Today+Saturday $\% 2 \mathrm{C}+8 \% 2 \mathrm{~F} 17$ _ COPY_01\&utm_medium=email\&utm_term=0_b5568df456-b21c420b1d-232422493

Persaud, F. (2020). Immigrants are dying for the US on the frontlines of this new war - but who cares? The New York Amsterdam News, 16 April.

Poo, A. (2020). Who cares? Now, all of us must. The New York Review of Books, 27 May. https:// portside.org/2020-06-11/who-cares-now-all-us-must

Rafael, V. L. (1995). Colonial domesticity: White women and United States rule in the Philippines. American Literature, 67(4 December), 639-666.

Reznick, A. (2020). 'You can either be a survivor or die': Covid-19 cases surge in ice detention. NPR, 1 July. https://www.npr.org/2020/07/01/871625210/ you-can-either-be-a-survivor-or-die-covid-19-cases-surge-in-ice-detention

Reyes-Velarde, A. (2020). Close-knit Latino family ties bring coronavirus dangers to traditional gatherings. Los Angeles Times, 4 September. https:/www.latimes.com/california/ story/2020-09-04/latinos-family-events-break-covid-19-protocol

Reiley, L. (2020). Migrant farmworkers, many coronavirus positive, more north from Florida to other states. The Washington Post, 11 June. https://www.washingtonpost.com/business/2020/06/11/migrant-farmworkers-many-who-have-tested-positive-covid-19-move-northflorida-other-farm-states/

Robles, F. (2020). Extending cruise ban, C.D.C. slams industry for spreading coronavirus. The New York Times, 16 July. https://www.nytimes.com/2020/07/16/travel/coronavirus-cruise-banextended.html

Saxton, A. (1971). The indispensable enemy: Labor and the Anti-Chinese movement in California. University of California Press.

Schloredt, V. (2020). How immigrant essential workers are finding support during COVID-19. Yes! Magazine, 6 July. https://www. yesmagazine.org/social-justice/2020/07/06/coronavirus-immigrants-essentialworkers/?utm_medium=email\&utm_campaign=YESDaily_20200707\&utm_ content=YESDaily_20200707+CID_a954e11de12375a5e449896376b748ad\& utm_source=CM\&utm_term $=$ Read $\% 20$ the $\% 20$ full $\% 20$ story

Shah, N. (2001). Contagious divides: Epidemics and race in San Francisco's Chinatown. University of California Press.

Shen, A. (2020). Why did it take a sterilization scandal to retrigger our outrage over ICE? Slate, 18 September. https://slate.com/news-and-politics/2020/09/ice-sterilization-scandal-outrageabuse-hysterectomies.html

Siripurapu, A. (2020). What is the defense production act? Council on Foreign Relations, 29 April. https://www.cfr.org/in-brief/what-defense-production-act

Schwenk, K. (2020). The ICE facility where almost every detainee has coronavirus. The American Prospect, 12 August. https://prospect.org/justice/ farmville-ice-facility-almost-every-detainee-has-coronavirus/

Tate, N. (2020). What changing death rates tell us about COVID-19. WebMD, 1 September. https:// www.webmd.com/lung/news/20200901/what-changing-death-rates-tell-us-about-covid

Trumka, R. (2020). Trump's dangerous decision on meatpacking plants. The New York Times, 7 May. https:/www.nytimes.com/2020/05/07/opinion/trump-meat-plants-coronavirus.html 
Tungohan, E. (2020). Filipino healthcare workers during COVID-19 and the importance of race-based analysis. Broadbent Institute, 1 May. https://www.broadbentinstitute.ca/ filipino_healthcare_workers_during_covid19_and_the_importance_of_race_based_analysis

United Nations. (2020). UN urges protection of domestic workers' rights during COVID-19 pandemic. Department of Global Communications. https://www.un.org/en/ un-urges-protection-domestic-workers $\%$ E2\% $80 \% 99$-rights-during-covid-19-pandemic

Urban, A. (2017). Brokering servitude: Migration and the politics of domestic labor during the long nineteenth century. NYU Press.

Villa, L. (2020). 'We're ignored completely.' Amid the pandemic, undocumented immigrants are essential but exposed. TIME, 17 April. https://news.yahoo.com/were-ignored-completelyamid-pandemic-204611520.html

Waltenburg, M. A., et al. (2020). Update: COVID-19 among workers in meat and poultry processing facilities - United States, April-May 2020. CDC Morbidity and Mortality Weekly Report, $69,887-892$.

Washington, J., \& Olivares, J. (2020). Number of women alleging misconduct by ICE gynaecologist nearly triples. The Intercept, 27 October. https://theintercept.com/2020/10/27/ ice-irwin-women-hysterectomies-senate/

Webster, D. (2020). Part Two: The 1918 flu pandemic that made cities. New Frame, 18 September. https://www.newframe.com/part-two-the-1918-flu-pandemic-that-made-cities/

White, J. H. (2014). Prodigal Sons and Beardless Machos: Labor, migration, and masculinity at Itaipu Binaclonal, Alto Paraná, Paraguay. Hispanic American Historical Review, 94(4 November), 649-679.

Wolfe, J. (2020). Domestic workers are at risk during the coronavirus crisis. Working Economics Blog, Economic Policy Institute, 8 April. https://www.epi.org/blog/domestic-workers-are-atrisk-during-the-coronavirus-crisis-data-show-most-domestic-workers-are-black-hispanic-orasian-women/

Open Access This chapter is licensed under the terms of the Creative Commons Attribution 4.0 International License (http://creativecommons.org/licenses/by/4.0/), which permits use, sharing, adaptation, distribution and reproduction in any medium or format, as long as you give appropriate credit to the original author(s) and the source, provide a link to the Creative Commons license and indicate if changes were made.

The images or other third party material in this chapter are included in the chapter's Creative Commons license, unless indicated otherwise in a credit line to the material. If material is not included in the chapter's Creative Commons license and your intended use is not permitted by statutory regulation or exceeds the permitted use, you will need to obtain permission directly from the copyright holder. 